\title{
THE COAGULATION DEFECT IN HEMOPHILIA: THE EFFECT, IN HEMOPHILIA, OF THE PARENTERAL ADMINIS- TRATION OF A FRACTION OF THE PLASMA GLOBULINS RICH IN FIBRINOGEN 1, 2,
}

\author{
By GEORGE R. MINOT, C. S. DAVIDSON, JESSICA H. LEWIS, H. J. TAGNON, \\ AND F. H. L. TAYLOR \\ (From the Thorndike Memorial Laboratory, Second and Fourth Medical Services (Harvard), \\ Boston City Hospital, and the Department of Medicine, Harvard Medical School, Boston)
}

(Received for publication March 3, 1945)

Previous studies from this laboratory have shown that normal human plasma, essentially free from formed elements, fibrinogen and prothrombin, can cause a marked reduction in the coagulation time of the blood in hemophilia when administered intravenously or intramuscularly (1). Furthermore, it was shown that such activity was associated with the plasma euglobulin of normal plasma (2) and was deficient in hemophilic blood (3). The preceding paper (4) has shown that this antihemophilic activity is largely present in Fractions I and III-2, obtained in the separation of the various globulin fractions of the plasma proteins.

The present communication concerns preliminary observations on the effects in vivo of the administration in hemophilia of small amounts of Fraction I. ${ }^{4}$ Fraction I contains from 60 to 70 per cent fibrinogen together with smaller amounts of other globulins.

\section{METHODS}

Four samples of Fraction I of the plasma globulins, prepared at different times by the Department of Physical

1 This is paper No. 39 in the "Studies of Plasma Proteins" of the Harvard Medical School, on products developed by the Department of Physical Chemistry, from blood collected by the American Red Cross.

2 The products of plasma fractionation employed in this work were developed from blood collected by the American Red Cross, by the Department of Physical Chemistry, Harvard Medical School, under contract recommended by the Committee on Medical Research, between the Office of Scientific Research and Development and Harvard University.

8 The expenses of this investigation were defrayed in part by gift from the Smith, Kline and French Laboratories, Philadelphia, and in part by a grant "In recognition of Dr. Francis W. Peabody's services to the Foundation" by the Ella Sachs Plotz Foundation.

\&We are indebted to Professor Edwin J. Cohn and Dr. John T. Edsall for furnishing the material on which these observations were made.
Chemistry of the Harvard Medical School (Numbers 162, $163,171,172)$, were used in this investigation. Numbers 162 and 163 were a pool of 7 sub-fractions of Fraction I. Their individual in vitro anti-hemophilic activity is shown in Table I. Five patients with classical hemophilia were studied. Sixteen injections of Fraction I were made in varying amounts either intravenously or intramuscularly.

The coagulation time at $37.5^{\circ} \mathrm{C}$. of the patient's blood was determined before, and at various intervals after, injection using the method of Pohle and Taylor (5). Prothrombin times were determined at the same time intervals as the coagulation times, using a modification of Quick's method in certain of the studies.

TABLE I

The effect of the addition of $0.1 \mathrm{ml}$. of the components of run 162 on the coagulation time of $2 \mathrm{ml}$. of hemophilic blood (in vitro)

\begin{tabular}{|c|c|c|c|c|c|}
\hline \multirow{2}{*}{ Fraction } & \multirow{2}{*}{$\begin{array}{l}\text { Control } \\
\text { C.T.* }\end{array}$} & \multicolumn{3}{|c|}{ Antihemophilic activity } & \multirow{2}{*}{ T.P.** } \\
\hline & & 0 & $\begin{array}{l}1 / 5 \\
\text { dilution }\end{array}$ & $\begin{array}{c}1 / 50 \\
\text { dilution }\end{array}$ & \\
\hline & minutes & \multicolumn{3}{|c|}{ minutes } & $\begin{array}{l}\text { grams per } \\
100 \mathrm{ml} .\end{array}$ \\
\hline $\begin{array}{l}162-1 \\
162-2 \\
163-1 \\
163-2 \\
163-3 \\
163-4 \\
163-5\end{array}$ & $\begin{array}{l}74 \\
74 \\
74 \\
74 \\
67 \\
67 \\
67\end{array}$ & $\begin{array}{l}53 \\
20 \\
16 \frac{1}{2} \\
13 \frac{1}{2} \\
22 \\
25 \\
26\end{array}$ & $\begin{array}{l}30 \\
22 \\
17 \frac{1}{2} \\
17 \\
19 \frac{1}{2} \\
19 \frac{1}{2} \\
22\end{array}$ & $\begin{array}{l}25 \\
46 \\
22 \\
32 \\
19 \frac{1}{2} \\
24 \\
21\end{array}$ & $\begin{array}{l}1.35 \\
1.29 \\
1.04 \\
1.63 \\
1.29 \\
1.34 \\
1.26\end{array}$ \\
\hline
\end{tabular}

* C.T. = coagulation time.

** T.P. $=$ total protein in original solution of fraction.

The materials used were received as dried powders and dissolved in small amounts of isotonic saline. Preparations of Fractions 162 and 163 were sterilized by passage though a Berkfeld filter. The other fractions were received from the Massachusetts Antitoxin and Vaccine Laboratory as sterile dry powder. These were dissolved in sterile isotonic saline solution and injected without further sterilization. The amounts injected in milligrams of protein are given in Table II.

In 1 patient, a comparison of the coagulation effect of whole blood, plasma and Fraction I was made. 
TABLE II

Effect of the parenteral administration of Fraction $I$ on the coagulation time of the blood in hemophilia

\begin{tabular}{|c|c|c|c|c|c|c|c|c|c|c|c|c|c|c|}
\hline \multirow{2}{*}{ Patient } & \multirow{2}{*}{$\begin{array}{c}\text { Run } \\
\text { no. }\end{array}$} & \multirow{2}{*}{$\begin{array}{l}\text { Protein } \\
\text { injected }\end{array}$} & \multirow{2}{*}{$\begin{array}{l}\text { Route of } \\
\text { injection }\end{array}$} & \multicolumn{11}{|c|}{ Coagulation time } \\
\hline & & & & $\begin{array}{c}\text { Pre- } \\
\text { injection } \\
\text { (control) }\end{array}$ & \multicolumn{10}{|c|}{ Post-injection } \\
\hline $\begin{array}{l}\text { J. C. } \\
\text { J. C. } \\
\text { W. G. } \\
\text { R. W. } \\
\text { J.S. } \\
\text { J. C. } \\
\text { R. W. } \\
\text { R. W. } \\
\text { R. W. } \\
\text { J. C. } \\
\text { J. C. } \\
\text { J. C. } \\
\text { J.S. } \\
\text { T. K. } \\
\text { J. C. } \\
T . \text { K. }\end{array}$ & $\begin{array}{c}162-163^{*} \\
162-163^{*} \\
162-163^{*} \\
162-163^{*} \\
171 \\
171 \\
171 \\
171 \\
171 \\
171 \\
171 \\
171 \\
171 \\
171 \\
172 \\
172\end{array}$ & $\begin{array}{c}\text { mgm. } \\
11.5 \\
125 \\
125 \\
125 \\
50+150 \dagger \\
50+150 \dagger \\
100 \\
100 \\
100 \\
100 \\
100 \\
100 \\
200 \\
200 \\
400 \\
600\end{array}$ & $\begin{array}{l}\text { I.V. } \\
\text { I.V. } \\
\text { I.M. } \\
\text { I.M. } \\
\text { I.V. } \\
\text { I.V. } \\
\text { I.V. } \\
\text { I.V. } \\
\text { I.V. } \\
\text { I.V. } \\
\text { I.V. } \\
\text { I.V. } \\
\text { I.V. } \\
\text { I.V. } \\
\text { I.V. } \\
\text { I.V. }\end{array}$ & $\begin{array}{c}\min . \\
96 \\
105 \\
168 \\
35 \\
36 \\
88 \\
33 \\
25 \\
35 \\
82 \\
38 \\
38 \frac{1}{2} \\
43 \\
62 \\
100 \\
52\end{array}$ & $\begin{array}{r}10 \text { min. } \\
\\
20 \\
172 \\
10\end{array}$ & $\begin{array}{c}\mathrm{h} h r . \\
46 \\
23 \\
140 \\
18 \\
21 \frac{1}{2} \\
21 \frac{1}{2} \\
13 \frac{1}{2} \\
19 \\
19 \\
19 \\
20 \\
17 \\
17 \\
19 \\
13 \frac{1}{2} \\
15\end{array}$ & $\begin{array}{c}1 \mathrm{hr} . \\
\\
210 \\
21 \\
18 \frac{1}{2} \\
23\end{array}$ & $\begin{array}{c}4 \text { hrs. } \\
50 \\
36 \\
40\end{array}$ & $\begin{array}{l}5 \text { hrs. } \\
22 \frac{1}{2} \\
19\end{array}$ & $\begin{array}{l}6 \text { hrs. } \\
\\
27 \\
20 \\
25 \\
21 \frac{1}{2} \\
20 \frac{1}{2} \\
37 \\
21 \\
29 \frac{1}{2} \\
21 \frac{1}{2} \\
16 \\
16 \frac{1}{2}\end{array}$ & $\begin{array}{c}8 \mathrm{hrs} . \\
112 \\
44 \\
\\
21 \frac{1}{2}\end{array}$ & \begin{tabular}{|c|}
24 hrs. \\
\\
72 \\
\\
38 \\
34 \\
25 \\
35 \\
32 \\
38 \\
$38 \frac{1}{2}$ \\
58 \\
35 \\
34 \\
34 \\
44
\end{tabular} & $\begin{array}{l}43 \\
72\end{array}$ & 72 hrs. \\
\hline
\end{tabular}

* Pooled Fraction I. Run 162 (Cut 1 and 2) and Run 163 (Cut 1 to 5).

† 20 minutes between injections.

RESULTS

The data are presented in Table II and Figures 1 and 2. With the exception of patient W. G. in whom the response to the injection was minimal, the administration of Fraction I produced a prompt and marked fall in the coagulation time of the patient's blood.

In one instance, a dose of $11.5 \mathrm{mgm}$. of protein

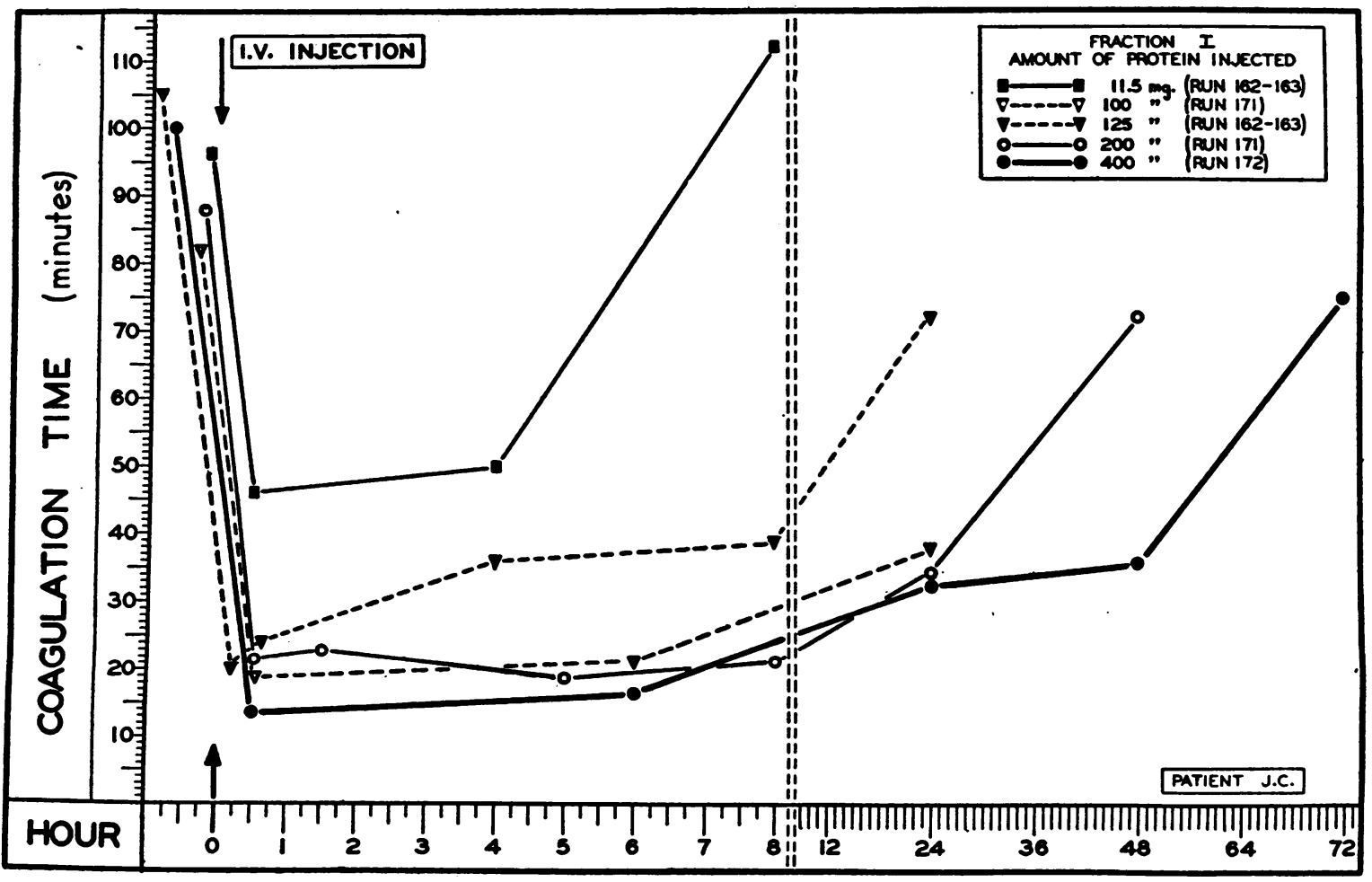

Fig. 1. Effect of Parenteral Administration of Fraction I on Clotting Time in Hemophinia 


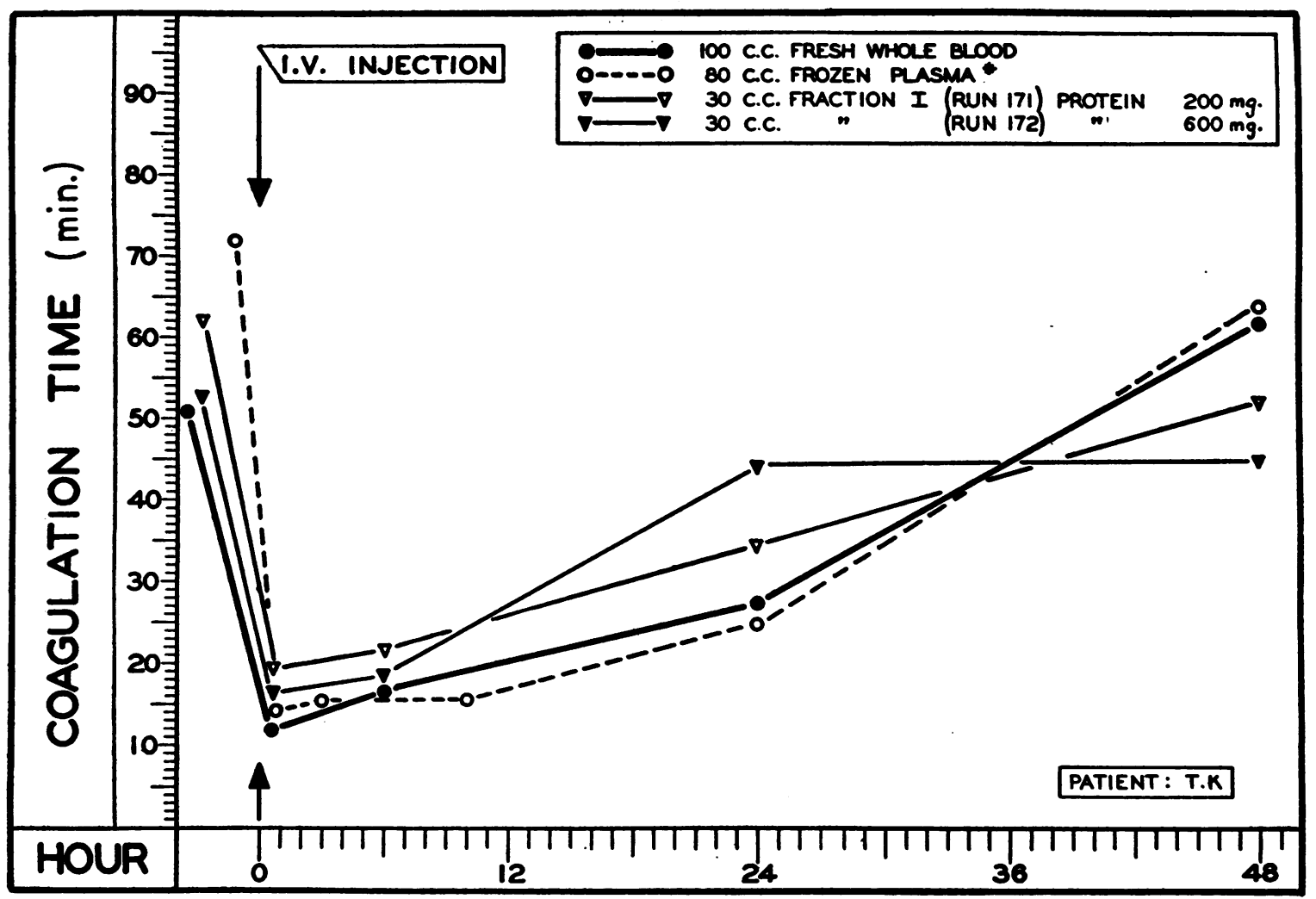

Fig. 2. Comparison of the Effects of Whole Blood, Blood Plasma and Fraction I, Given Parenterally, on Clotting Time in Hemophilia

* Plasma obtained from fresh whole blood and immediately frozen to minus $20^{\circ} \mathrm{C}$.

gave a marked drop in the coagulation time of the patient's blood. The fall was not optimal and the duration of the effect was not long. With amounts between 100 and $200 \mathrm{mgm}$. of protein the coagulation time fell toward normal limits and occasionally reached them. The duration of the effective reduction for clinical purposes lasted from 6 to 8 hours although the coagulation time of the blood 24 hours after injection was usually prolonged but often shorter than the control coagulation time.

When more than $200 \mathrm{mgm}$. were injected the blood coagulation time reached normal limits and the evidence indicates a somewhat longer period of effective reduction. The data of Figure 1 indicate the changes in the coagulation time of the blood of patient J. C. using various amounts of Fraction I.

Experience in this laboratory has shown that the injection of $80 \mathrm{ml}$. of fresh plasma or $100 \mathrm{ml}$. of whole blood is an effective therapeutic proce- dure in reducing the coagulation time of the patient's blood to normal prior to surgical procedure. The effectiveness of 200 and $600 \mathrm{mgm}$. of the protein of Fraction I were compared to the effectiveness of $80 \mathrm{ml}$. of plasma and $100 \mathrm{ml}$. of whole blood. The results are shown in Figure 2. It would appear that from 200 to $600 \mathrm{mgm}$. of the protein were on the whole just as effective as the amounts of whole blood and plasma generally used in this clinic. The duration of the effect was approximately the same.

As shown by the data of Table I, in 1 patient there was no essential difference between the intramuscular and intravenous routes of administration. There was no change in the prothrombin time of the patients following the administration of the globulin fraction.

It is of some practical interest that the injection of a patient with an active globulin fraction had no influence on the effectiveness of subsequent injections of the material. 


\section{DISCUSSION}

The preliminary data show that a sharp fall in the coagulation time of the blood in hemophilia follows the intravenous administration of as little as $11.5 \mathrm{mgm}$. of the protein of Fraction I. Since it is known that 60 to 70 per cent of the Fraction I protein is fibrinogen (6) and that globulin fractions devoid of fibrinogen are active (1), it can be stated reasonably that the amount of antihemophilic factor injected could be much smaller than the total amount of protein administered. Hence further separation of the protein of Fraction I may well further reduce the amounts of the active protein required to produce effective reduction of the coagulation time of the blood in hemophilia. Some suggestions that this may eventually be accomplished are given in the preceding paper (4) where it is shown that a fibrinogen-free fraction (Fraction III-2) has marked anti-hemophilic activity in vitro.

The hemophilic patient who failed to respond satisfactorily to the injection of $125 \mathrm{mgm}$. of the protein of Fraction I, responds poorly even to the injection of $250 \mathrm{ml}$. of normal human plasma. His coagulation time is often 170 minutes. He has not returned to this clinic and thus no information is available as to effect of larger doses. It is possible that even he might have responded to such larger doses of the globulin.

The dosage required of the material is not known and will require a considerable amount of investigation using fractions of the same potency. At present it appears that from 200 to 600 mgm. of the protein are as effective as $80 \mathrm{ml}$. of plasma or $100 \mathrm{ml}$. of whole blood.

The only untoward reaction observed was a slight sclerosis of an injected vein in one instance. The degree of sclerosis was of trivial magnitude such as is often encountered following the injection of 50 per cent glucose solution. Since the fraction was administered in high concentration and quite rapidly, future consideration of these points probably will remove this objectionable feature. The same patient has been reinjected on several occasions without this untoward reaction.

These observations clearly indicate that Fraction I of Cohn is an active anti-hemophilic preparation. This communication does not suggest that it is the most active of the globulin preparations. Our investigations for the future will determine whether other fractions are more or less active than Fraction I.

\section{CONCLUSIONS}

The administration, intravenously or intramuscularly, of small amounts of the globulin fraction (Fraction I) of pooled normal human plasma reduced the blood coagulation time of hemophilic blood toward or to normal values in 15 out of 16 instances where it was employed. One of these patients responded to as little as $11.5 \mathrm{mgm}$. of the globulin. In 1 patient, the effect of the intramuscular administration of $125 \mathrm{mgm}$. of the protein was minimal. The dosage for therapeutic use has not been established but 200 to $600 \mathrm{mgm}$. of the globulin have an effect equal to that obtained by $80 \mathrm{ml}$. of fresh plasma or $100 \mathrm{ml}$. of whole blood.

\section{BIBLIOGRAPHY}

1. Lozner, E. L., Kark, R., and Taylor, F. H. L., The coagulation defect in hemophilia: the clot promoting activity in hemophilia of berkefelded normal human plasma free from fibrinogen and prothrombin. J. Clin. Invest., 1939, 18, 603.

2. Lozner, E. L., and Taylor, F. H. L., The coagulation defect in hemophilia: studies of the clot promoting activity associated with plasma euglobulin in hemophilia. J. Clin. Invest., 1939, 18, 821.

3. Patek, A. J., Jr., and Taylor, F. H. L., Hemophilia. II. Some properties of a substance obtained from normal human plasma effective in accelerating the coagulation of hemophilic blood. J. Clin. Invest., 1937, 16, 113.

4. Taylor, F. H. L., Davidson, C. S., Tagnon, H. J., Adams, M. A., MacDonald, A. H., and Minot, G. R., Studies in blood coagulation. The coagulation properties of certain globulin fractions of normal human plasma in vitro. J. Clin. Invest., 1945, 24, 698.

5. Pohle, F. J., and Taylor, F. H. L., The coagulation defect in hemophilia. The effect in hemophilia of intramuscular administration of a globulin substance derived from normal human plasma. J. Clin. Invest., 1937, 16, 741.

6. Cohn, E. J., Oncley, J. L., Strong, L. E., Hughes, W. L., Jr., and Armstrong, S. H., Jr., Chemical, clinical, and immunological studies on the products of human plasma fractionation. I. The characterization of the protein fractions of human plasma. J. Clin. Invest., 1944, 23, 417. 